
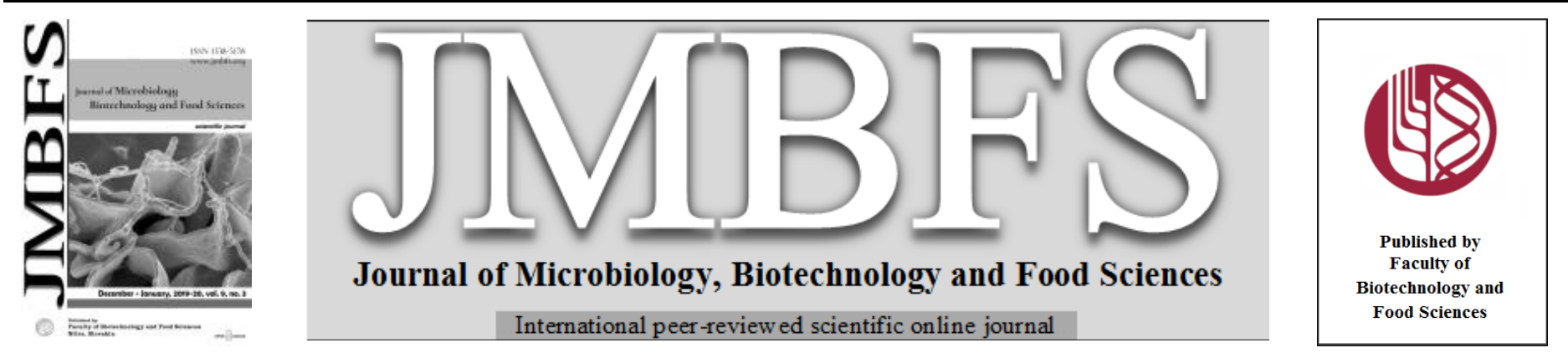

\title{
PURIFICATION AND BIOCHEMICAL CHARACTERIZATION OF ASPARTIC PEPTIDASE PRODUCED BY NOVEL ISOLATE MUCOR CIRCINELLOIDES (VON TIEGHEM) USING SSF PROCESS
}

\author{
Souhila Bensmail ${ }^{* 1,2}$, Fethia Naimi-Fazouane ${ }^{1}$ \\ Address(es): \\ ${ }^{1}$ Research Laboratory of Food Technology, Faculty of Engineering Sciences, M'hamed Bougara University, 35000, Boumerdes, Algeria. \\ ${ }^{2}$ Department of Biological Sciences, Faculty of Nature, Life and Earth Sciences, Akli Mohand Oulhadj University, 10000, Bouira, Algeria.
}

*Corresponding author: $\underline{\text { s.bensmail@univ-boumerdes.dz }}$

doi: $10.15414 / j m b f s .2019 / 20.9 .3 .590-598$

\section{ARTICLE INFO}

Received 25. 4. 2019

Revised 7. 6. 2019

Accepted 10.6.2019

Published 1. 12. 2019

Regular article OPEN $\partial_{\text {ACCESS }}$

\begin{abstract}
Microbial peptidases are among the most important hydrolytic enzymes which have a potential application in a wide number of industrial processes. In this study, the milk-clotting enzyme of a newly isolated strain Mucor circinelloides (von Tieghem) MG603064 was produced by solid-state fermentation using wheat bran as the substrate. The crude extract exhibited a maximum milk-clotting activity of $1500 \pm$ $50.94 \mathrm{SU} / \mathrm{mL}$ after $72 \mathrm{~h}$ of incubation at $25^{\circ} \mathrm{C}$. Purification of the enzyme using fractionation at $20-70 \%\left(\mathrm{NH}_{4}\right)_{2} \mathrm{SO}_{4}$ followed by size exclusion chromatography on Sephadex G-100 allowed us to obtain a 20 -fold purified peptidase with a recovery of $18.41 \%$. The highest activity of the purified enzyme $(30 \mathrm{kDa})$ was obtained in $25 \mathrm{mM} \mathrm{CaCl}_{2}$, at $\mathrm{pH} 5.0$ and temperature of $60{ }^{\circ} \mathrm{C}$. The enzyme was stable between $\mathrm{pH} 3.0-4.5$ for $24 \mathrm{~h}$ at $4{ }^{\circ} \mathrm{C}$ in $0.1 \mathrm{M}$ citrate buffer and retained more than $80 \%$ of its maximum activity at $45^{\circ} \mathrm{C}$ for $1 \mathrm{~h}$ with complete inactivation at $75{ }^{\circ} \mathrm{C}$. The enzyme inhibition of 94.5 and $98.6 \%$ by 0.02 and $0.1 \mathrm{mM}$ Pepstatin A, respectively, confirmed that the enzyme is an aspartyl peptidase. A partial inhibition of $78.17 \%$ was noted for EDTA at $14 \mathrm{mM}$. The enzyme activity was improved significantly by $\mathrm{Mg}^{2+}, \mathrm{Fe}^{2+}, \mathrm{Mn}^{2+}$ and $\mathrm{Zn}^{2+}$ by $40.5,59.5,75.6$ and $85 \%$, respectively, and strongly inhibited by $\mathrm{Al}^{3+}(93.1 \%)$ and $\mathrm{Hg}^{2+}(94.4 \%)$, at a concentration of $10 \mathrm{mM}$. Activity stimulation of $120 \%$ was maximum in the presence of $\mathrm{Ba}^{2+}$ using the same concentration. The crude and pre-purified extracts were applied in a trial of semi-hard cheese making (type Edam) as possible rennet substitutes.
\end{abstract}

Keywords: Milk clotting activity, peptidases, Mucor circinelloides, purification, cheese making

\section{INTRODUCTION}

Most of the enzymes currently developed for industrial applications are obtained from microorganisms and might constitute $90 \%$ of the global market (Hirose, 2012; Guerrand, 2017). Food processing industries utilized nearly about $29 \%$ of total produced enzymes, and out of this 58\% are obtained from fungi (Ahlawat et al., 2018). More than one hundred enzymes from fungal origin have been commercialized from 25 genera including Aspergillus, Rhizopus, Trichoderma, Penicillium, and Humicola. Fungal hydrolases are the most important class of enzymes with applications in different fields like in food and beverage industries (Money, 2016).

Peptidases or "peptide hydrolases" represent one of the three major groups of industrial enzymes and occupy $60 \%$ of total worldwide enzyme sales, of which microbial peptidases, as the leaders of industrial enzymes, account for approximately 40\% (Ahlawat et al., 2018; Mamo \& Assefa, 2018).

Milk coagulation is the first stage in a typical cheese manufacture, besides milk pasteurization and possibly the addition of starter bacteria. For most cheese varieties $(\approx 75 \%$ of total cheese $)$, this step is achieved by adding small amount of chymosin (EC 3.4.23.4) (also termed rennin), which represents the ideal and bestknown dairy enzyme used in cheese production due to its high specificity for $\kappa$ casein (Walsh, 2014; Nasr et al., 2016).

The reduced worldwide supply of calf rennin, its high price, and the everincreasing cheese production in combination with other factors have encouraged the search for substitutes from alternative sources such as animals, plants, and microbial peptidases (Shah et al., 2014; Walsh, 2014; Nasr et al., 2016). Research on microbial coagulants has resulted in the production of fungal aspartic peptidases characterized by low heat tolerance and low levels of proteolytic activity (Yegin and Dekker, 2013; Mamo and Assefa, 2018).

All microbial coagulants are produced commercially by fungal fermentation and are secreted directly into the culture medium in a dilute form free of cell proteins. This greatly simplifies the downstream process, where few subsequent purification steps are required to concentrate these enzymes, remove contaminating enzymes (peptidases, lipases and amylases), and improve the curdling activity (Harboe $\boldsymbol{e t}$ al., 2010; Yegin et al., 2011).

According to the literature, only affinity chromatography with $\mathrm{N}$-acetylpepstatin and $\mathrm{N}$-isobutyrylpepstatin has been effectively used for the purification of microbial aspartic peptidases (Preetha and Boopathy, 1997), but conventional gel filtration and ion-exchange chromatographic methods have also been successfully used for the purification of these enzymes with high purification level (Kumar $\boldsymbol{e}$ al., 2005; El-Bendary et al., 2007) that can reach to 220.9-fold (Khalil Moghaddam et al., 2008).

Few works have been published on milk-clotting peptidases production by strains of Mucor circinelloides, study of their properties and possible applications specifically in cheese manufacture. The present study was carried out to purify and to identify the properties of an extracellular rennin-like enzyme produced by novel isolate Mucor circinelloides (von Tieghem). Semi-hard cheese (type Edam) trials from cow milk were done using the crude and pre-purified extracts produced by the strain, and their performance was compared to that obtained by the commercial rennin.

\section{MATERIAL AND METHODS}

Chemicals

Ammonium sulfate and EDTA were purchased from AnalaR NORMA PUR ${ }^{\circledR}$ VWR International Prolabo (Leuven, Belgium). Bovine serum albumin, Folin Ciocalteu reagent, Pepstatin A, 2-mercaptoethanol and prestained molecular markers for electrophoresis were obtained from Sigma-Aldrich (St. Louis, USA) Sephadex G-100, PMSF and Coomassie Brillant Blue R-250 were from Pharmacia Fine Chemicals INC. (Uppsala, Sweden), Thermo Scientific (USA) and Panreac Quimica (Barcelona, Spain) respectively. All the other chemicals were of analytical grade. 


\section{Enzyme production by SSF}

Mucor circinelloides 2095-2047 was isolated from agricultural soil (El-Hadjout, Tipaza, Alegria) and identified by the Belgian Co-Ordinated Collections of MicroOrganisms, Laboratory of Mycology, the Catholic University of Louvain-la-Neuve (BCCM-MUL, Belgium) using macroscopic and microscopic observations; and by molecular method (ITS sequence identification). It was successfully integrated into the GenBank database, and it has accession number of MG603064. The strain was maintained on potato dextrose agar (PDA) slants and sub-cultured once every two months.

The milk-clotting enzyme (MCE) was produced by the strain through solid-state fermentation (SSF) process under previously determined optimizing conditions as following: $10 \mathrm{~g}$ of wheat bran (purchased from a local market) containing $1 \%$ solid ammonium sulfate $\left(\mathrm{NH}_{4}\right)_{2} \mathrm{SO}_{4}$ were taken in $250 \mathrm{~mL}$ conical flasks moistened by the mineral solution M-9 (Tunga et al., 1998) ( $\mathrm{pH} 4.23)$ to achieve a moisture content of $56.1 \%$. After autoclaving $\left(115^{\circ} \mathrm{C}\right.$ for $\left.15 \mathrm{~min}\right)$ and cooling, the medium was inoculated with the optimum spore count of $12.6 \times 10^{7}$ spores $/ \mathrm{mL}$ (developed previously on PDA medium during 5-7 d, then recovered by a sterile solution of $0.1 \%$ Tween 80 ) and cultivated at $25^{\circ} \mathrm{C}$.

After every $24 \mathrm{~h}$ of incubation, over a period of $168 \mathrm{~h}$, the MCE was extracted from the moldy bran (one entire SSF flask) with $50 \mathrm{~mL}$ of sterile distilled water by shaking at $160 \mathrm{rpm}$ for $2 \mathrm{~h}$ in a rotary shaker (MaxQ 4000, Model 4331, Thermo Scientific ${ }^{\mathrm{TM}}$, Marietta, USA) at $30{ }^{\circ} \mathrm{C}$, followed by centrifugation at $2504 \times \mathrm{g}$ for 15 min at $4{ }^{\circ} \mathrm{C}$ (HERMLE, refrigerated centrifuge model Z300K, Germany). The supernatant thus obtained represents the crude enzymatic extract.

\section{Purification of the milk-clotting enzyme}

\section{Ammonium sulfate precipitation}

In the first purification step, proteins from the crude extract were subjected to fractionation by adding solid ammonium sulfate as described by Burgess (2009) to determine the optimal precipitation conditions of the MCE. Precise quantities of $\left(\mathrm{NH}_{4}\right)_{2} \mathrm{SO}_{4}$, were added gradually and separately to $10 \mathrm{~mL}$ of the crude extract in five tubes, with slow stirring at $0{ }^{\circ} \mathrm{C}$ for $30-45 \mathrm{~min}$ to achieve $20 \%, 30 \%, 40 \%$, $50 \%$, and $60 \%$ saturations. The saturated solutions were centrifuged and solid $\left(\mathrm{NH}_{4}\right)_{2} \mathrm{SO}_{4}$ was again added to the recovered supernatants to raise each to a $10 \%$ higher level of saturation. After $16-18 \mathrm{~h}$ at $4{ }^{\circ} \mathrm{C}$, five pellets of $20-30 \%, 30-40 \%$, $40-50 \%, 50-60 \%$ and $60-70 \%$ saturation were collected by centrifugation $(2504$ $\times g, 30 \mathrm{~min}$ at $4{ }^{\circ} \mathrm{C}$ ), then re-suspended in a small volume of citrate/sodium phosphate buffer $(0.1 \mathrm{M}, \mathrm{pH} 5.2)$ and assayed for enzyme activities and total protein content.

\section{Dialysis against buffer}

The pellet resulting from the optimal $\left(\mathrm{NH}_{4}\right)_{2} \mathrm{SO}_{4}$ fractionation was introduced into a dialysis tubing membrane (Size 9-36/32, diameter $28.6 \mathrm{~mm}$, MWCO 12-14 kDa, Medicell Membranes Ltd, London, UK) and dialyzed at $4{ }^{\circ} \mathrm{C}$ against several changes of citrate/sodium phosphate buffer $(0.1 \mathrm{M}, \mathrm{pH} 5.2)$ over a $24 \mathrm{~h}$ period to remove residual salt. The dilute enzyme preparation was concentrated for $2 \mathrm{~h}$ against $50 \%$ sucrose solution and kept at $4{ }^{\circ} \mathrm{C}$ for further purification.

\section{Gel filtration chromatography}

A required amount of Sephadex G-100 was suspended in an excess volume of citrate/sodium phosphate buffer $(0.1 \mathrm{M}, \mathrm{pH} 5.2)$. After swelling, the gel was washed twice by the same buffer to eliminate the fine particles and then heated at $90{ }^{\circ} \mathrm{C}$ for $3 \mathrm{~h}$ to degas the medium. Then, $1 \mathrm{~mL}$ of the dialyzed extract was applied to a $1.5 \times 30 \mathrm{~cm}$ column (DWK Life Sciences Kimble ${ }^{\mathrm{TM}}$ Flex-Columns ${ }^{\mathrm{TM}}$, Fisher Scientific, USA) crammed with the gel and equilibrated with citrate/sodium phosphate buffer $(0.1 \mathrm{M}, \mathrm{pH}$ 5.2). The column was linked to a Spectra/Chrom Fraction Collector CF-2 (Spectrum Labs ${ }^{\mathrm{TM}}$, Houston, USA) and REGLO Digital MS-2/6 peristaltic pump (ISMATEC, Wertheim, Germany). Fractions of $2 \mathrm{~mL}$ were collected at a flow rate of $0.3 \mathrm{~mL} / \mathrm{min}$. The fractions with high milk-clotting activity were pooled and concentrated by dialyzing against a sucrose solution at $50 \%$ and ultra-filtration using an Amicon ${ }^{\circledR}$ Ultra-4 Centrifugal Filter Unit with a $10-\mathrm{kDa}$ cut off (MILLIPORE Corporation, Massachusetts, USA), by centrifugation at $2504 \times g$.

\section{Polyacrylamide gel electrophoresis}

Protein profiles of the enzyme purification steps were analyzed by SDS-PAGE using 5\% stacking and $10 \%$ resolving gels, and performed according to the method of Laemmli, (1970) under reducing conditions. Samples were mixed with SDS reducing buffer (ratio $1: 2 \mathrm{v} / \mathrm{v}$ ) containing $0.5 \mathrm{M}$ Tris- $\mathrm{HCl}(\mathrm{pH} 6.8), 4 \%$ SDS, $20 \%$ glycerol, $0.004 \%$ bromophenol blue, and $10 \%$ 2-mercaptoethanol, and then heated at $95{ }^{\circ} \mathrm{C}$ for $5 \mathrm{~min}$. After loading the samples into the stacking gel, they were migrated at a constant current of $70 \mathrm{~V}$ for $30 \mathrm{~min}$ and at $120 \mathrm{~V}$ for about $2 \mathrm{~h}$ in the separating gel. Separated proteins were visualized by staining the resolving gel with $0.15 \%$ Coomassie Brillant Blue R-250 in $10 \%$ acetic acid for $24 \mathrm{~h}$, then destaining by a mixture of $40 \%$ methanol, $10 \%$ acetic acid and $50 \%$ distilled water. The molecular weight was determined using prestained molecular weight markers (SDS7B2): Triosphosphate isomerase from Rabbit Muscle (26.6 kDa), Lactic dehydrogenase from Rabbit Muscle (36.5 kDa), Fumarase from Porcine Heart (48.5 kDa), Pyruvate kinase from Rabbit Muscle (58 kDa), Lactoferrin from Human Milk (90 kDa), $\beta$-Galactosidase from E. coli $(116 \mathrm{kDa})$ and $\alpha_{2}$ Marcroglobulin from equine serum (subunit) (180 kDa).

\section{Enzyme assays}

\section{Milk-Clotting Activity (MCA)}

Assay of milk-clotting activity was done according to the method of Arima et al. (1970) using skim milk powder prepared by $10 \mathrm{~g}$ dissolved in $100 \mathrm{~mL}$ of $0.01 \mathrm{M}$ $\mathrm{CaCl}_{2}$ (pH 6.40) as substrate. To $10 \mathrm{~mL}$ of substrate $(\mathrm{S})$ pre-incubated at $35^{\circ} \mathrm{C}$ for $15 \mathrm{~min}, 1 \mathrm{~mL}$ of the enzyme extract (E) was added. The MCA was expressed in Soxhlet Unit (SU). One Soxhlet unit is defined as the volume of milk, that one volume of enzyme preparation is able to clot in $40 \mathrm{~min}$ at $35^{\circ} \mathrm{C}$, and is calculated by the formula: MCA $(\mathrm{SU} / \mathrm{mL})=2400 \times \mathrm{S} / \mathrm{E} \times \mathrm{T}$

Coagulation time $(\mathrm{T})$ is the time (s) elapsed between the addition of the enzyme extract to the substrate and the appearance of clots on the inner wall of test tube

\section{Protease Activity (PA)}

The proteolytic activity was measured by a modified method of Anson (1938). The substrate was prepared by $2.5 \mathrm{~g}$ of casein in $100 \mathrm{~mL}$ of $0.1 \mathrm{M}$ citrate/sodium phosphate buffer ( $\mathrm{pH} 5.2$ ). The reaction mixture consisted of $2.5 \mathrm{~mL}$ of casein solution, $0.5 \mathrm{~mL}$ of enzyme preparation and $0.5 \mathrm{~mL}$ of the same buffer, was incubated at $40{ }^{\circ} \mathrm{C}$ for $30 \mathrm{~min}$. The reaction was terminated by adding $5 \mathrm{~mL}$ of $4 \%$ pre-chilled trichloroacetic acid (TCA). The blank was prepared in the same conditions but TCA solution was added before the enzyme extract. After filtration through Whatman paper no.1 to eliminate the resultant precipitate, the concentration of the TCA-soluble products was measured by the change of the absorption at $750 \mathrm{~nm}$ (UV-1800 Shimadzu Corporation spectrophotometer, Kyoto, Japan) using Folin-Ciocalteu reagent. One unit (U) of activity represents the amount of enzyme required to liberate $1 \mu \mathrm{g}$ of tyrosine from the substrate per min under assay conditions.

\section{Protein content}

Estimations of the protein concentration in the different enzymatic extracts were determined following the method of Bradford (1976) using bovine serum albumin as a standard. The protein content of the individual fractions obtained after gel filtration chromatography was evaluated by measuring the absorbance at $280 \mathrm{~nm}$ (UV-1800 Shimadzu Corporation spectrophotometer, Kyoto, Japan).

\section{Characterization of the purified enzyme}

\section{Optimum pH and temperature}

The effect of temperature on the MCA of the purified extract was investigated under the standard assay conditions. First, $2.5 \mathrm{~mL}$ of the substrate were preincubated at different temperatures varying from $25-75^{\circ} \mathrm{C}$. After $15 \mathrm{~min}, 0.25 \mathrm{~mL}$ of enzyme extract were added and the milk-clotting time was determined in each case.

The optimal $\mathrm{pH}$ of the MCE was determined by measuring the clotting time of the reaction mixture at milk $\mathrm{pH}$ in the range from 5.0-8.0 adjusted with $\mathrm{HCl}$ and/or $\mathrm{NaOH}(1 \mathrm{~N})$ solutions. The MCA was determined as previously described (10\% skimmed milk in $0.01 \mathrm{M} \mathrm{CaCl}_{2}, 35^{\circ} \mathrm{C}$ ).

The curdling activity was expressed in percentage relative to the highest activity obtained (the shortest clotting time).

\section{pH and thermal heat stability}

The $\mathrm{pH}$ stability was determined by measuring the residual MCA of the enzyme solution maintained at $4{ }^{\circ} \mathrm{C}$ for $24 \mathrm{~h}$ in $0.1 \mathrm{M}$ citrate buffer $(\mathrm{pH} 3-5)(\mathrm{v} / \mathrm{v})$ and 0.1 M phosphate buffer (pH 6-8) (v/v).

Study of the thermal stability was carried out by incubating the enzyme extracts at temperatures ranging from $30-75^{\circ} \mathrm{C}$ in citrate/sodium phosphate buffer $(0.1 \mathrm{M}$; $\mathrm{pH}$ 5.2) for $1 \mathrm{~h}$.

The residual MCA, expressed as a percentage relative to the initial MCA, was determined according to the standard conditions of measurement.

\section{Effect of $\mathrm{CaCl}_{2}$ and $\mathrm{NaCl}$ on $\mathrm{MCA}$}

The optimal concentration of calcium chloride $\left(\mathrm{CaCl}_{2}\right)$ was determined by observing the coagulation time under standard assay conditions using substrates 
prepared with precise concentrations of $\mathrm{CaCl}_{2}(10 \%$ skim milk powder in $5 \mathrm{mM}$ to $50 \mathrm{mM} \mathrm{CaCl}_{2}$ ).

To evaluate the effect of sodium chloride $(\mathrm{NaCl})$ addition on the MCA of the purified enzyme, the standard substrate was prepared with increasing concentrations of $\mathrm{NaCl}$ from $1-10 \%(\mathrm{w} / \mathrm{v})$ (Ahmed and Helmy, 2012). The activity was expressed in percentage relative to that measured in the absence of the salt.

\section{Inhibition assays}

The effects of four inhibitors: Phenylmethylsulphonyl fluoride (PMSF), 2 mercaptoethanol, Pepstatin-A and Ethylenediaminetetraacetic acid (EDTA) at different concentrations on the MCA of the purified enzyme were tested after incubating with each inhibitor separately for $30 \mathrm{~min}$ at $35^{\circ} \mathrm{C}$ (Yegin et al., 2012). The impact of different metal ions $\left(\mathrm{CuSO}_{4}, \mathrm{FeSO}_{4}, \mathrm{MgSO}_{4}, \mathrm{MnSO}_{4}, \mathrm{ZnSO}_{4}\right.$ $\mathrm{HgSO}_{4}, \mathrm{KCl}, \mathrm{AlCl}_{3}, \mathrm{BaCl}_{2}, \mathrm{NaCl}$ and $\mathrm{NH}_{4} \mathrm{Cl}$ ) was tested under the same conditions at concentrations of $5 \mathrm{mM}$ and $10 \mathrm{mM}$.

The residual MCA was measured following the standards conditions, and the activity calculated in the absence of inhibitor or metal ion was taken as $100 \%$

\section{Effect of substrate concentration}

The values of $K_{m}$ and $V_{\max }$ of the purified enzyme were determined using casein as a substrate with concentrations in the range from $1.0-3.5 \%$ prepared in citrate/sodium phosphate buffer $(0.1 \mathrm{M}, \mathrm{pH}$ 5.2). For each concentration of casein, a blank was prepared as previously described. The two kinetic parameters were determined graphically from the Linweaver-Burk plot.

\section{Cheese making}

Bovine raw milk was used in trials of semi-hard cheese making (Edam, continental cheese) in order to get an estimate on the quality of the fungal extracts and their potential for cheese production.

The milk (pH: 6.61, fat: $34 \mathrm{~g} / \mathrm{L}$, total solids: $118.08 \mathrm{~g} / \mathrm{L}$, with total absence of antibiotics) was heat treated at $90{ }^{\circ} \mathrm{C}$ for $15 \mathrm{~s}$, and cooled to a constant temperature of $38{ }^{\circ} \mathrm{C}$. Then $0.3 \mathrm{~g} / \mathrm{L} \mathrm{CaCl}_{2}, 0.3 \mathrm{~g}$ lactic starter cultures: FD-DVS R-707 (Lactococcus lactis subsp. cremoris; Lactococcus lactis subsp. lactis), FD-DVS ST-B01 (Streptococcus thermophilus) (Chr. Hansen, Denmark), and four to five drops of diluted colorant E160b at 1\% (Annatto extract) were added to milk. After stirring during $10 \mathrm{~min}$, the milk ( $\mathrm{pH} 6.4)$ was divided into three equal portions and separately inoculated with $0.5 \mathrm{~mL}$ of commercial rennin CHY-MAX ${ }^{\circledR}(600$ IMCU/mL, Chr. Hansen, Denmark) prepared in water $(0.166 \mathrm{~g} / \mathrm{mL}), 10.8 \mathrm{~mL}$ of the crude extract, or $1.33 \mathrm{~mL}$ of the dialyzed extract produced by $M$. circinelloides. The volume of each coagulant was standardized to start coagulation within $10 \mathrm{~min}$ for a known volume of milk, based on preliminary tests.

After complete coagulation and hardening $(25-40 \mathrm{~min})$, the cheese curds were cut into cubes (the size of corn kernel $>0.5 \mathrm{~cm} \sim 1.0 \mathrm{~cm}$ ) during $15-20 \mathrm{~min}$. The cut curds were allowed to settle for $5 \mathrm{~min}$ and then washed with a precise volume of water $\left(40{ }^{\circ} \mathrm{C}\right)$ following the first step of whey elimination to reduce acidity. After $20 \mathrm{~min}$, the second whey was removed and the curd grains were transferred into rounded molds with cheese cloths, pressed for 20-30 min (2-3 bars), then inverted and pressed again (4.5-6 bars) until the evacuated whey reached a $\mathrm{pH}$ of 5.40 and the cheeses reached their desired shape. The resulting cheese blocks were immerged in salt brine $(33 \%, \mathrm{w} / \mathrm{v})$ for $5 \mathrm{~h}$ at $10-14{ }^{\circ} \mathrm{C}$. After drying for $24 \mathrm{~h}$, they were transferred into a ripening room $\left(85-95 \%\right.$ humidity at $10-12{ }^{\circ} \mathrm{C}$ ) for $3-4$ weeks and inverted twice a week. For the last steps, the surface of cheeses was scarped and washed with water, recovered with melted red paraffin wax (110-115 ${ }^{\circ} \mathrm{C}$ ) and vacuum-packed in cellophane foil to prevent drying, then stored at $6{ }^{\circ} \mathrm{C}$.

The analyses of cheese were performed using standard methods: determination of $\mathrm{pH}$ by direct contact with grated cheese using a $\mathrm{pH}$-meter (Hanna instruments, Romania), dry matter/moisture by drying at $102{ }^{\circ} \mathrm{C}$ to constant weight (IDF Standard 4A:1982, AOAC Method 926.08), and fat content determination was done according to the Gerber-van Gulik method (IDF Standard 5B:1986; AOAC Method 933.05) (Ardö and Polychroniadou, 1999)

\section{Statistical Analysis}

All assays were carried out in triplicate and each result is the mean value of three trials \pm standard deviation. The confidence level for statistical significance was considered at $P<0.05$; and was calculated using Excel software version 7.0.

\section{RESULTS AND DISCUSSION}

\section{Production of the crude extract}

The crude extract produced by $M$. circinelloides under the optimal conditions exhibited the highest MCA of $1500 \pm 50.943 \mathrm{SU} / \mathrm{mL}$ with MCA/PA ratio $=41.34$ \pm 0.20 after $72 \mathrm{~h}$ of incubation at $25^{\circ} \mathrm{C}$ (Tab 1$)$. The maximum proteolytic activity of $39.325 \pm 0.55 \mathrm{U} / \mathrm{mL}$ was obtained after $96 \mathrm{~h}$, which was probably caused by the production of other non-specific peptidase(s).

MCA expressed directly by the crude extract was higher than those produced by fungal strains: Thermomucor indicae-seudaticae N31 (Merheb-Dini et al., 2010), Rhizopus microsporus var. rhizopodiformis (Sun et al., 2014), and Rhizomucor miehei EMCC 841 (NRRL 3420) (Aljammas et al., 2018), as well as by the bacterial species: Bacillus subtilis natto (Wu et al., 2011), B. amyloliquefaciens SP1 (Guleria et al., 2016) and B. methanolicus LB-1 (Li et al., 2019) through solid or liquid fermentations as follows: $167.6 \mathrm{SU} / \mathrm{mL}, 1001 \mathrm{SU} / \mathrm{mL}, 600 \mathrm{SU} / \mathrm{mL}$ 1043.5 SU/mL, $142 \mathrm{SU} / \mathrm{mL}, 578.4 \mathrm{SU} / \mathrm{mL}$, respectively.

From the Table 1, a pH decline to a low value of 5.32 was observable (determined after addition of distilled water to the moldy bran) followed by an increase, which is in accordance with previous research, indicated that activation of the microbial coagulants required a $\mathrm{pH}$ reduction (Harboe $\boldsymbol{e t}$ al., 2010). The decrease in MCA after $72 \mathrm{~h}$ was probably caused by the reduction of nutrients and deactivation by other metabolites.

Table 1 Evolution of $\mathrm{pH}$ and enzymatic activities of the crude extract produced by M. circinelloides as function of the fermentation time.

\begin{tabular}{lcccc}
\hline $\begin{array}{l}\text { Incubatio } \\
\text { n time }(\mathrm{h})\end{array}$ & MCA $(\mathrm{SU} / \mathrm{mL})$ & PA $(\mathrm{U} / \mathrm{mL})$ & $\begin{array}{c}\text { MCA/PA } \\
\text { ratio }\end{array}$ & $\begin{array}{c}\mathrm{pH} \text { of the } \\
\text { crude } \\
\text { extract }\end{array}$ \\
\hline 24 & $13.15 \pm 0.18$ & $15.65 \pm 1.80$ & $0.84 \pm 0.09$ & 6.13 \\
48 & $679.36 \pm 11.00$ & $33.42 \pm 0.17$ & $20.33 \pm 0.26$ & 5.47 \\
72 & $1500.00 \pm 50.94$ & $36.28 \pm 0.18$ & $41.34 \pm 0.20$ & 5.32 \\
96 & $1359.48 \pm 45.28$ & $39.32 \pm 0.55$ & $34.57 \pm 1.63$ & 5.66 \\
120 & $1125.54 \pm 30.00$ & $36.17 \pm 1.03$ & $31.12 \pm 1.67$ & 6.28 \\
144 & $1014.5 \pm 25.10$ & $35.84 \pm 0.66$ & $28.30 \pm 0.41$ & 6.43 \\
168 & $692.44 \pm 11.64$ & $34.67 \pm 1.28$ & $19.97 \pm 1.09$ & 6.61 \\
\hline
\end{tabular}

MCA: milk-clotting activity. PA: proteolytic activity.

The results were shown as mean value \pm standard deviation of three replicates.

One entire SSF flask was harvested for each sample point.

\section{Purification of MCE}

The first step of purification was fractionation with solid $\left(\mathrm{NH}_{4}\right)_{2} \mathrm{SO}_{4}$ which represents the most commonly used precipitant for salting out of proteins, due to its high solubility at any temperature, low cost, protection of proteins in solution from denaturation, and its stabilizing effect on most enzymes (Hirose, 2012; Walsh, 2014).

From all of the fractions resulting after precipitation (Tab 2), the fraction $\mathrm{P} 4$ was had the highest MCA, best MCA/PA ratio, and the highest degree of purification, with a recovery in activity of $307.7 \%$ and a yield of $46.15 \%$, followed by the fraction P5.

The pellet recovered after precipitation using $\left(\mathrm{NH}_{4}\right)_{2} \mathrm{SO}_{4}$ at $20 \%$ saturation and the supernatant of the fraction P5 exhibited a proteolytic activity of $8.70 \pm 0.68 \mathrm{U} / \mathrm{mL}$ and $13.21 \pm 0.30 \mathrm{U} / \mathrm{mL}$, respectively with no clotting activity (clotting time was more than $120 \mathrm{~min}$ ). Thus, the fraction P6 was recovered to be compared to the other five fractions. The recovery in activity of $300 \%(P=0.232>0.05)$ and the MCA/PA ratio of $46.62(P=0.082>0.05)$ were very close to that obtained with the fraction P4 (no significant differences). In addition, we noted a yield of $60 \%$ 
which was higher than those of the two fractions P4 and P5 were. Consequently, the fraction P6 was considered superior and was loaded onto the Sephadex G-100 column after dialysis.

Table 2 Precipitation of the milk-clotting enzyme of $M$. circinelloides with solid ammonium sulfate

\begin{tabular}{|c|c|c|c|c|c|c|c|c|c|}
\hline & $\begin{array}{l}\text { Total } \\
(\mathrm{SU})\end{array}$ & MCA & $\begin{array}{l}\text { Total protein } \\
(\mathrm{mg})\end{array}$ & $\begin{array}{l}\text { PA } \\
(\mathrm{U} / \mathrm{mL})\end{array}$ & $\begin{array}{l}\mathrm{MCA} / \mathrm{PA} \\
\text { ratio }\end{array}$ & $\begin{array}{l}\text { Recovered } \\
\text { MCA }(\%)\end{array}$ & $\begin{array}{l}\text { Specific } \\
\text { MCA } \\
(\mathrm{SU} / \mathrm{mg})\end{array}$ & $\begin{array}{l}\text { Fold } \\
\text { purity }\end{array}$ & $\begin{array}{l}\text { Yield } \\
(\%)\end{array}$ \\
\hline Crude extract* & $\begin{array}{l}5714.30 \\
142.87\end{array}$ & \pm & $4.75 \pm 0.343$ & $37.80 \pm 0.717$ & $\begin{array}{l}15.12 \pm \\
0.66\end{array}$ & 100.00 & 1203.01 & 1.00 & 100.0 \\
\hline P1 (20-30\%) & $\begin{array}{l}111.87 \pm \\
3.331\end{array}$ & & $0.126 \pm 0.007$ & $15.91 \pm 0.738$ & $\begin{array}{l}4.70 \pm \\
0.145\end{array}$ & $\begin{array}{l}13.05 \pm \\
0.40\end{array}$ & 887.85 & 0.74 & 1.96 \\
\hline P2 (30-40\%) & $\begin{array}{l}180.00 \pm \\
1.566\end{array}$ & & $0.242 \pm 0.067$ & $22.04 \pm 0.414$ & $\begin{array}{l}5.44 \pm \\
0.11\end{array}$ & $\begin{array}{l}21.00 \pm \\
0.183\end{array}$ & 743.80 & 0.62 & 3.15 \\
\hline P3 (40-50\%) & $\begin{array}{l}233.76 \pm \\
2.276\end{array}$ & & $0.405 \pm 0.035$ & $23.72 \pm 1.655$ & $\begin{array}{l}6.57 \pm \\
0.43\end{array}$ & $\begin{array}{l}27.27 \pm \\
0.265\end{array}$ & 577.20 & 0.48 & 4.09 \\
\hline P4 (50-60\%) & $\begin{array}{l}2637.36 \pm \\
114.2\end{array}$ & & $1.23 \pm 0.05$ & $35.62 \pm 0.254$ & $\begin{array}{l}49.0 \pm \\
2.465\end{array}$ & $\begin{array}{l}307.70 \pm \\
13.323\end{array}$ & 2144.20 & 1.78 & 46.15 \\
\hline P5 (60-70\%) & $\begin{array}{l}1742.86 \pm \\
49.50\end{array}$ & & $0.855 \pm 0.104$ & $33.54 \pm 0.147$ & $\begin{array}{l}34.64 \pm \\
0.83\end{array}$ & $\begin{array}{l}203.33 \pm \\
5.773\end{array}$ & 2038.43 & 1.70 & 30.50 \\
\hline P6 (20-70\%) & $\begin{array}{l}3428.60 \pm \\
131.96\end{array}$ & & $2.09 \pm 0.063$ & $36.77 \pm 0.350$ & $\begin{array}{l}46.22 \pm \\
1.852\end{array}$ & $\begin{array}{l}300.00 \pm \\
11.55\end{array}$ & 1640.48 & 1.36 & 60.00 \\
\hline
\end{tabular}

*The crude extract used in the optimization of salting out fractionation by $\left(\mathrm{NH}_{4}\right)_{2} \mathrm{SO}_{4}$ differs from the one used in the purification process.

Analytical methods were applied directly without using dialysis to remove salt from the pellets. MCA: milk-clotting activity. PA: proteolytic activity.

The results were shown as mean value \pm standard deviation of three replicates.

Recovered MCA $(\%)=\left(\frac{\text { Iniial activity of fraction } \mathrm{X}}{\text { Initial activity of the crude extract }}\right) \times 100$, Specific MCA $=$ Total activity (SU) , Fold purity $=\frac{\text { Specific activity of fraction } \mathrm{X}}{\text { Origin }}$

Total protein $(\mathrm{mg})$ Fol

Yield $(\%)=\left(\frac{\text { Total activity of fraction } \mathrm{X}}{\text { Total original activity }}\right) \times 100$

The dialyzed extract was separated to three peaks of proteins using Sephadex G100 , where only one peak exhibited MCA, which was eluted from fraction no.10 to fraction no.22 (Fig 1). Similar findings have been reported by El-Bendary $\boldsymbol{e t}$ al. (2007), Nouani et al. (2009) and El-Tanboly et al. (2013), using Sephadex G-100 to purify milk-clotting extracts produced by B. sphaericus NRC 24 , M. pusillus, and $M$. pusillus $\mathrm{QM} 436$ respectively. The results of the purification procedure were summarized in Table 3 .

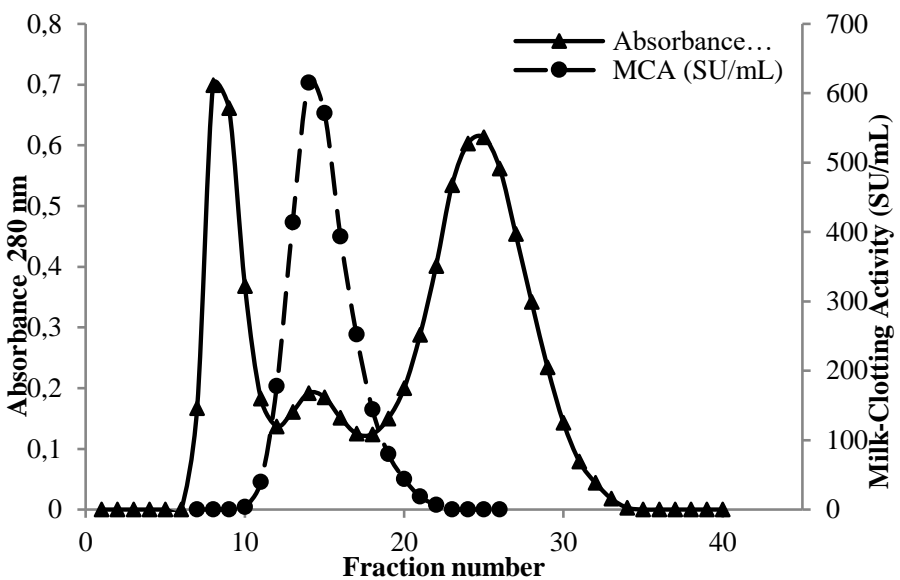

Figure 1 Elution profile of fraction P6 on Sephadex G-100 (Column $30 \mathrm{~cm} \times 1.5$ $\mathrm{cm})$ eluted with citrate/sodium phosphate buffer $(0.1 \mathrm{M}, \mathrm{pH} 5.2)$, flow rate $=0.3$ $\mathrm{mL} / \mathrm{min}$, fraction $=2 \mathrm{~mL}$.
Fractionation with $\left(\mathrm{NH}_{4}\right)_{2} \mathrm{SO}_{4}$ at $20-70 \%$ of saturation followed by dialysis allowed the removal of $82.63 \%(37.35 \mathrm{mg})$ of the contaminating proteins from the crude extract and resulted in a 6.445 -fold purification. According to the literature, as with any precipitation method, the salting out is not very selective and led to purification factors below 10, even under optimized conditions, which limits the use of $\left(\mathrm{NH}_{4}\right)_{2} \mathrm{SO}_{4}$ as a means of concentrating proteins (Illanes, 2008).

High recoveries of biological activity are usually recorded using $\left(\mathrm{NH}_{4}\right)_{2} \mathrm{SO}_{4}$ precipitation (Walsh, 2014). In this study, a yield of $111.9 \%$ was obtained after dialysis, used to remove the salt, resulted from inhibitors and/or heavy metal ions elimination. Similarly, a very close yield of $103.3 \%$ was reached after fractionation of the milk-clotting extract produced by $R$. oryzae with solid $\left(\mathrm{NH}_{4}\right)_{2} \mathrm{SO}_{4}($ Kumar et al., 2005).

After Sephadex G100-column, the peptidase of $M$. circinelloides, free of brown pigmentation (Fig 2), was purified 19.9-fold with a recovery of $18.41 \%$ and a high specific activity of $20202 \mathrm{SU} / \mathrm{mg}$ of protein. The decrease in proteolytic activity from $36.28 \pm 0.82 \mathrm{U} / \mathrm{mL}$ to $23.37 \pm 0.80 \mathrm{U} / \mathrm{mL}$ resulted from elimination of nonspecific peptidases during the purification process and thus enhanced the quality of the purified extract as a possible rennin substitute.

\begin{tabular}{|c|c|c|c|c|c|c|c|}
\hline Purification steps & $\begin{array}{l}\text { Total MCA } \\
\text { (SU) }\end{array}$ & $\begin{array}{l}\text { Total protein } \\
(\mathrm{mg})\end{array}$ & $\begin{array}{l}\mathrm{PA} \\
(\mathrm{U} / \mathrm{mL})\end{array}$ & $\begin{array}{l}\text { Specific } \\
\text { (SU/mg) }\end{array}$ & $\mathrm{MCA}$ & $\begin{array}{l}\text { Fold } \\
\text { purity }\end{array}$ & $\begin{array}{l}\text { Yield } \\
(\%)\end{array}$ \\
\hline Crude extract & $\begin{array}{l}45875.00 \pm \\
1025.26\end{array}$ & $45.20 \pm 1.78$ & $36.28 \pm 0.82$ & 1014.93 & & 1.00 & 100.00 \\
\hline $\begin{array}{l}\left(\mathrm{NH}_{4}\right)_{2} \mathrm{SO}_{4} \text { fractionation } \\
\text { at } 20-70 \%\end{array}$ & $\begin{array}{l}36000.00 \pm \\
1484.50\end{array}$ & $23.89 \pm 1.033$ & $39.60 \pm 0.91$ & 1507.06 & & 1.48 & 78.47 \\
\hline Dialyzed extract & $\begin{array}{l}51333.33 \pm \\
8082.90\end{array}$ & $7.85 \pm 0.434$ & $34.10 \pm 0.60$ & 6541.78 & & 6.44 & 111.90 \\
\hline Sephadex $G-100^{a}$ & $\begin{array}{l}8444.44 \pm \\
88.63\end{array}$ & $0.42 \pm 0.13$ & $23.37 \pm 0.80$ & 20202.00 & & 19.90 & 18.41 \\
\hline
\end{tabular}

${ }^{\mathrm{a}}$ : fractions from no.11 to no. 21 were pooled then concentrated by dialysis against sucrose.

MCA: milk-clotting activity. PA: proteolytic activity.

The results were shown as mean value \pm standard deviation of three replicates. 


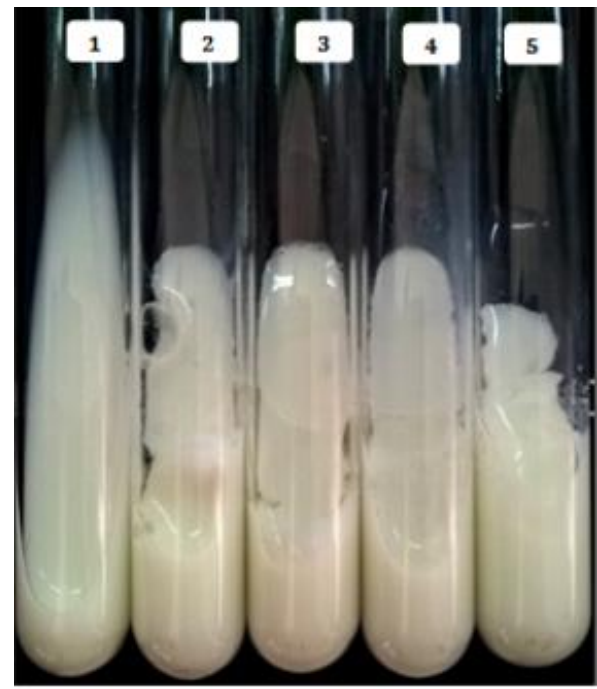

Figure 2 Coagulation of skimmed milk by the crude extract and purified enzyme of M. circinelloides (1: control, 2: crude extract, 3: precipitated pellet with 20-70\% $\left(\mathrm{NH}_{4}\right)_{2} \mathrm{SO}_{4}, 4$ : dialyzed extract, $\mathbf{5}$ : purified enzyme).

The purified peptidase of $M$. circinelloides, which migrated as a single band of 30 $\mathrm{kDa}$ in SDS-PAGE under reducing and non-reducing conditions, suggested that the purified protein is monomeric (Fig 3). The MCE was expressed as the main protein in the crude extract, like in most cases of Mucor spp., produced only one main MCE in the culture supernatants (Yegin et al., 2011).

Our results are in agreement with several cases of fungal aspartic peptidases presenting a monomeric structure with low molecular weights between $30-35 \mathrm{kD}$ (Kumar et al., 2005; Vishwanatha et al., 2010; Yegin et al., 2012; Benlounissi et al., 2014).

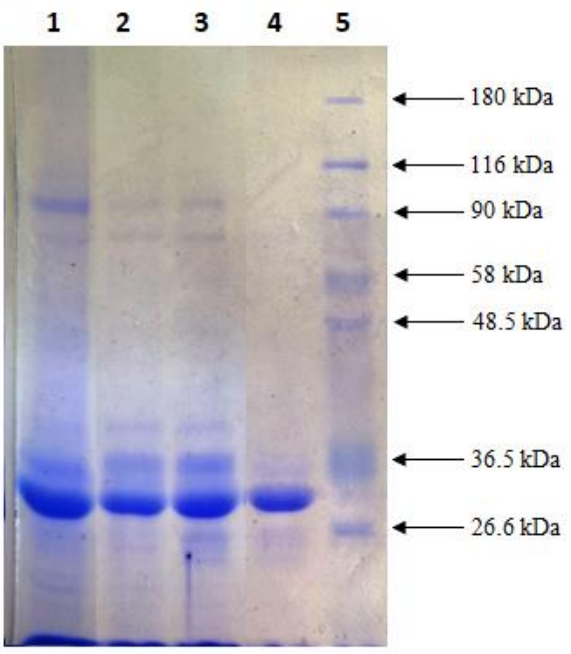

Figure 3 Electrophoretic profile of enzymatic extracts of $M$. circinelloides during purification steps on SDS-PAGE (lane 1: crude extract, lane 2: precipitated fraction with $20-70 \%\left(\mathrm{NH}_{4}\right)_{2} \mathrm{SO}_{4}$, lane 3: dialyzed extract, lane 4: purified enzyme, lane $\mathbf{5}$ : Molecular weight markers).

\section{pH optima and pH stability}

It is known that $\mathrm{pH}$ affects the rate of renneting, curd firmness, and syneresis, as well as fat recovery, $\mathrm{Ca}^{2+}$ retention, and the final texture of cheese (Maciel et al., 2015)

The effect of $\mathrm{pH}$ on the MCA of $M$. circinelloides peptidase is illustrated in Figure 4a. The results show a maximum activity at $\mathrm{pH} 5.0$, then a gradual decrease with increasing milk $\mathrm{pH}$, and a complete inactivation at $\mathrm{pH}$ 7.5. According to Yegin and Dekker (2013), the optimum $\mathrm{pH}$ for the hydrolysis of $\kappa$-casein has been reported as from 5.1-5.3. The chymosin acted optimally on $\kappa$-casein at a $\mathrm{pH}$ very close to 5.5 (Kumar et al., 2010), while rennet was more active at pH 5.0 (Nouani et al., 2009; Zikiou and Zidoune, 2018).

The MCA cannot be processed at $\mathrm{pH}$ values below 5.0, because the caseins in milk are insoluble at their isoelectric points $(\mathrm{pH} \sim 4.6)$ at temperatures $>\sim 8{ }^{\circ} \mathrm{C}$ (Guinee and $O^{\prime} B$ Brien, 2010) and clot without adding enzymatic solutions.

Similar finding were noted by Nouani et al. (2009), Yegin et al. (2012) and Celebi et al. (2016). Characterization of coagulant enzymes from B. amyloliquefaciens $\mathrm{D} 4$ (He et al., 2011), M. pusillus QM 436 (El-Tanboly et al., 2013), T. indicae- seudaticae N31 (Silva et al. 2013), and R. microsporus var. rhizopodiformis (Sun et al., 2014), revealed that all are active at an acidic $\mathrm{pH}$, with an optimum for MCA between 5.2-5.5.

The purified MCE of $M$. circinelloides retained its maximum clotting activity (about $80 \%$ ) in the $\mathrm{pH}$ range from 3.0-4.5 after incubation for $24 \mathrm{~h}$ at $4{ }^{\circ} \mathrm{C}$ in 0.1 $\mathrm{M}$ citrate buffer (Fig 4b). The same results were obtained with $0.1 \mathrm{M}$ citrate/sodium phosphate buffer. Raising the $\mathrm{pH}$ induced a rapid decrease in the clotting activity until it was closely deactivated at $\mathrm{pH}$ 8.0. A good stability in the same range of $\mathrm{pH}$ was noted for the milk-clotting peptidases of A. niger FFB1 (Fazouane-Naimi $\boldsymbol{e}$ al., 2010) and $T$. indicae-seudaticae N31 (Merheb-Dini et al., 2010; Silva et al., 2013)

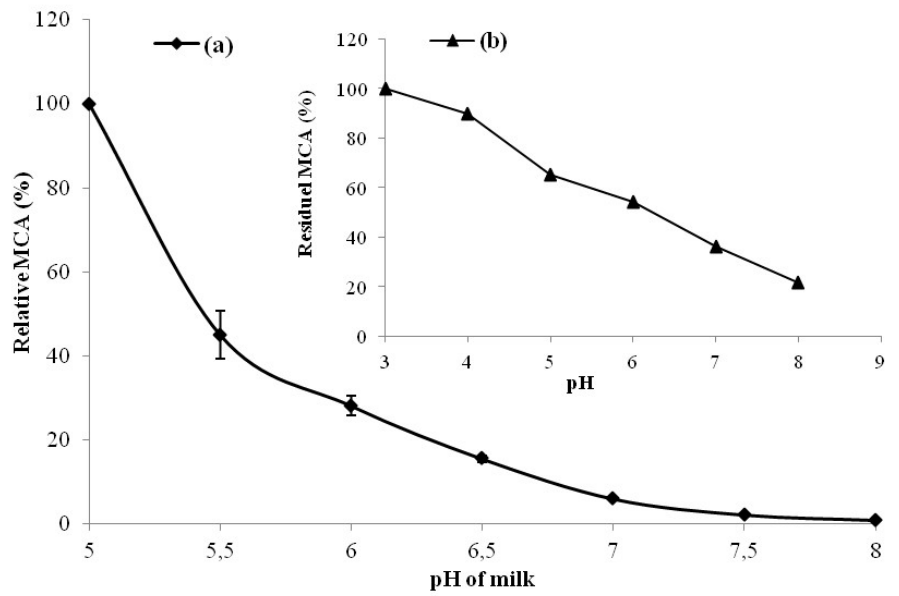

Figure 4 Effect of milk pH (a) on MCA of the purified enzyme (milk temperature $35^{\circ} \mathrm{C}, 0.01 \mathrm{M}$ of $\mathrm{CaCl}_{2}$ ) and its $\mathrm{pH}$ stability (b) after $24 \mathrm{~h}$ of incubation at $4{ }^{\circ} \mathrm{C}$. Error bars represent the standard deviation of three replicates.

Temperature optima and thermostability

According to results presented in Figure 5a, the maximum activity was reached at $60{ }^{\circ} \mathrm{C}$, which is similar to that detected for milk-clotting peptidases produced by R. oryzae (Kumar et al., 2005), M. pusillus QM 436 (El-Tanboly et al., 2013), B. subtilis natto (Wu et al. 2013) and R. microsporus var. rhizopodiformis (Sun et al., 2014). A lower activity was obtained with the other temperatures tested, and it was abolished at $70^{\circ} \mathrm{C}$ due to the instability of the conformational structure of the enzyme.

The optimal temperature for the MCA of microbial coagulants varied from one species to another. It was $40{ }^{\circ} \mathrm{C}$ and $45^{\circ} \mathrm{C}$ for M. mucedo DSM 809 (Yegin et al. 2012) and A. niger FFB1 (Fazouane-Naimi et al., 2010), respectively; $50^{\circ} \mathrm{C}$ in the case of $R$. miehei (Celebi et al., 2016) and B. methanolicus LB-1 (Li et al., 2019); and $55^{\circ} \mathrm{C}$ for peptidase produced by A. oryzae MTCC 5431 (Vishwanatha et al., 2010). However, others coagulants were more active at highest temperatures of $65-70{ }^{\circ} \mathrm{C}$ (Merheb-Dini et al., 2010; He et al., 2011; Ding et al., 2012)

The clotting activity of the purified enzyme was stable up to $45^{\circ} \mathrm{C}$, with more than $80 \%$ of maximum activity (Fig $5 \mathrm{~b}$ ). The activity decreased to $13 \%$ after incubation at $60{ }^{\circ} \mathrm{C}$ for $1 \mathrm{~h}$, and it was completely inactive at $70-75{ }^{\circ} \mathrm{C}$ because of the denaturation of the enzyme.

The same range of stability $\left(30-45{ }^{\circ} \mathrm{C}\right)$ has been reported for the coagulan enzymes of $R$. oryzae (Kumar et al., 2005), A. niger FFB1 (Fazouane-Naimi $\boldsymbol{e}$ al., 2010), $T$. indicae-seudaticae N31 (Merheb-Dini et al., 2010) and more than $70 \%$ of activity was retained up to $45^{\circ} \mathrm{C}$ in the case of peptidase produced by $R$ microsporus var. rhizopodiformis (Sun et al., 2014),

Generally, microbial coagulants have a higher thermal stability than calf rennet (Celebi et al., 2016), in which aspartic peptidases from Mucor spp. are more thermolabile than those that were obtained from Rhizomисоr spp. currently used in cheese making (Yegin and Dekker, 2013).

The purified enzyme of $M$. circinelloides was more sensitive to heat treatment and retained only $55 \%$ of its activity at $55^{\circ} \mathrm{C}$, compared to peptidases produced by $M$ pusillus (Nouani et al., 2009), T. indicae-seudaticae N31 (Silva et al., 2013), and Rhizomucor pusillus (Yegin and Dekker, 2013) that preserved more than $70 \%$ of activity at the same temperature. While under similar conditions, calf chymosin (Merhe-Dini et al., 2010) and coagulant enzymes produced by M. mucedo DSM 809 (Yegin et al., 2012) and R. microsporus var. rhizopodiformis (Sun et al., 2014) were completely inactivated.

In cheese manufacture, the high thermal stability of a coagulant prevents the usage of whey and results in the persistence of activities particularly the proteolytic one $(0-15 \%)$ after the cooking of the curd, causing off-flavors, bitterness, and texture defects in the cheese during long maturation periods (Merheb-Dini et al., 2010; Celebi et al., 2016). Therefore, the ability of the purified enzyme to be rendered closely inactive by moderate heating, favors its application in the cheese manufacture. 


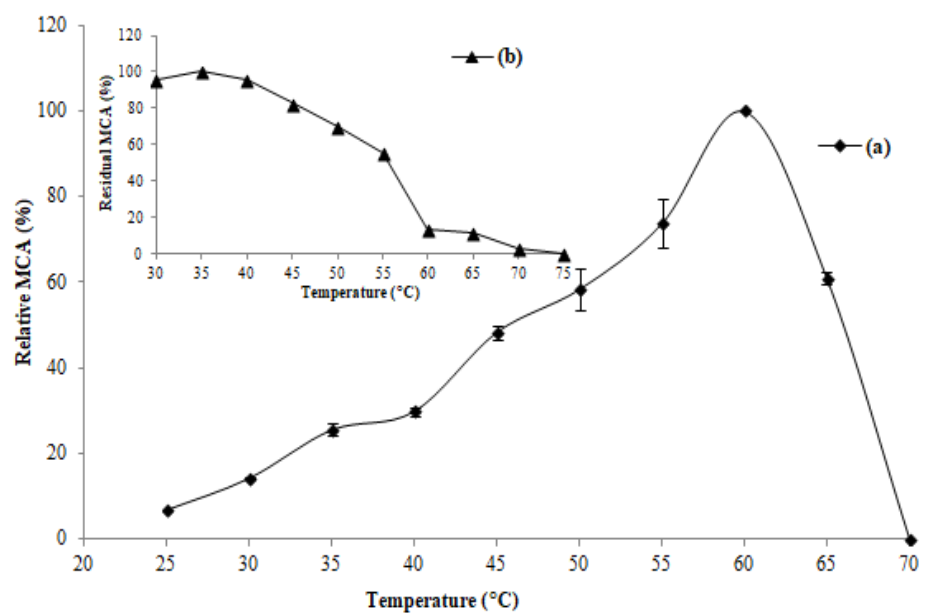

Figure 5 Influence of temperature (a) on MCA of the purified enzyme (milk pH 6.40; $0.01 \mathrm{M}$ of $\mathrm{CaCl}_{2}$ ), and its thermal stability (b) after $60 \mathrm{~min}$ of incubation. Error bars represent the standard deviation of three replicates.

\section{The optimum concentration of $\mathrm{CaCl}_{2}$}

According to Figure 6, the MCA is optimal at a low $\mathrm{CaCl}_{2}$ concentration of 25 $\mathrm{mM}$. The decrease in activity at higher concentrations than this could be explained by the progressive saturation of negative residues (phosphoserine and carboxylic groups) of the casein micelles or the increase of ionic force (Merheb-Dini et al., 2010; He et al., 2011). Similar behavior has been reported by He et al. (2011) and Li et al. (2019).

The optimal activity of rennet was found at $20 \mathrm{mM} \mathrm{CaCl}_{2}$ in the substrate (Nouani et al., 2009; Zikiou and Zidoune, 2018; $\mathrm{Li}$ et al., 2019), while for other peptidases, the MCA reached its maximum with $40 \mathrm{mM}$ (Merheb-Dini $\boldsymbol{e}$ al., 2010; Silva et al., 2013; Sun et al., 2014) and $60 \mathrm{mM} \mathrm{CaCl}_{2}$ (Ding et al., 2012). Addition of calcium chloride to cheese milk presents several advantages: it speed up the curd formation, improves curd firmness, and the slight drop in $\mathrm{pH}$ promotes the action of the coagulant and increases the rate of casein micelles aggregation during the second phase (non-enzymatic) of coagulation (Harboe $\boldsymbol{e t}$ al., 2010; Merheb-Dini et al., 2010; Vishwanatha et al., 2010; El-Tanboly et al., 2013). However, according to Silva et al. (2013), the excess of $\mathrm{CaCl}_{2}$ may result in the formation of a bitter taste in cheese, thus it is more useful to reach the maximum activity of coagulant at low concentrations of $\mathrm{CaCl}_{2}$.

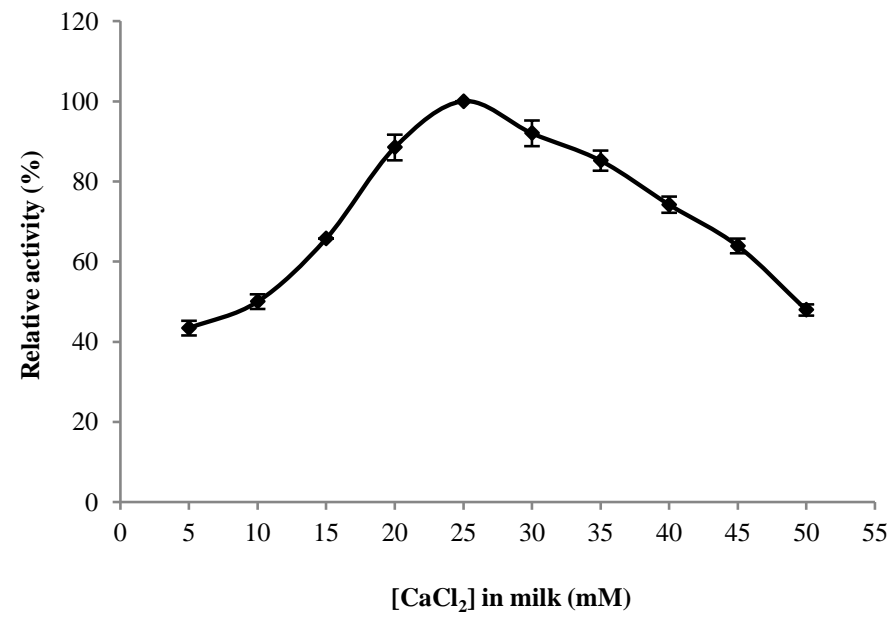

Figure 6 Influence of $\mathrm{CaCl}_{2}$ concentration on MCA of the purified enzyme of $M$ circinelloides (temperature and $\mathrm{pH}$ of milk: $35^{\circ} \mathrm{C}, 6.40$ ). Error bars represent the standard deviation of three replicates.

\section{Effect of sodium chloride}

Milk is sometimes salted with $\mathrm{NaCl}$ for protection against spoilage by various microorganisms. The amount of salt required to reduce water activity to prevent microbial growth is 4-5\% (Ahmed and Helmy, 2012).

The MCA of the purified enzyme was rapidly decreased by increasing the $\mathrm{NaCl}$ concentration (Fig 7). The low concentration of $\mathrm{NaCl}$ at $1 \%$ induced a significant decrease in the activity to reach only $41.4 \%$. The findings are in agreement with the results previously obtained (El-Bendary et al., 2007; El-Tanboly et al., 2013) It was suggested that $\mathrm{NaCl}$ such as $\mathrm{CaCl}_{2}$ affected the hydrolysis of casein through some conformational changes in casein rather than the enzyme (Salehi et al., 2017), where it promotes dissociation of calcium and phosphate from within casein micelles and into solution, which reduce the rennet coagulability of milk (Awad, 2007).

In order to avoid the loss of MCA, it is more suitable to apply the purified enzyme in the cheese manufacture using unsalted milk

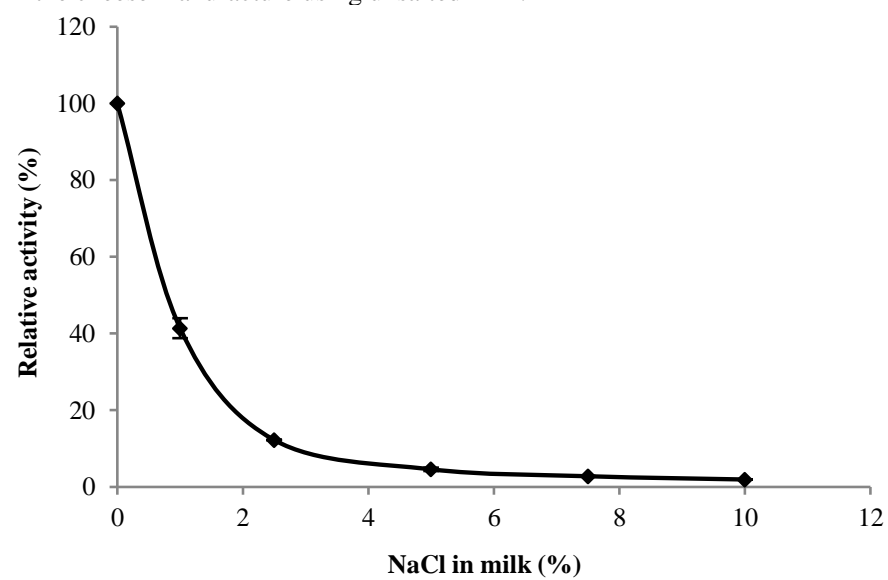

Figure 7 Effect of $\mathrm{NaCl}$ concentration on MCA of the purified enzyme of $M$. circinelloides (temperature and $\mathrm{pH}$ of milk: $35^{\circ} \mathrm{C}, 6.40 ; 0.01 \mathrm{M}$ of $\mathrm{CaCl}_{2}$ ). Error bars represent the standard deviation of three replicates.

\section{Protease inhibitors}

The effects of various inhibitors on the MCA of the purified enzyme were investigated to identify the peptidase class (Tab 4). A very low inhibition was observed with the highest concentrations tested of PMSF (serine peptidases inhibitor) and 2-mercaptoethanol (cysteine peptidases inhibitor) where the enzyme conserved more than $87 \%$ and $93 \%$ of its original activity, respectively.

The enzyme retained $74.2 \%$ of its activity in $5 \mathrm{mM}$ EDTA (metallopeptidases inhibitor), which decreased to approximately $22 \%$ with a concentration of $14 \mathrm{mM}$. These results are in agreement with those reported by Hashem (2000) and Sun $\boldsymbol{e t}$ al. (2014), but most of the milk-clotting peptidases previously studied have been insensitive to the action of EDTA (Kumar et al., 2005; El-Bendary $\boldsymbol{e t}$ al., 2007; Vishwanatha et al., 2010), or their activity was enhanced using low concentrations (Merheb-Dini et al., 2010; Yegin et al., 2012).

Theron and Divol (2014) as well as Mamo and Assefa (2018) reported the role of $\mathrm{Ca}^{2+}$ ions as cofactor for aspartic peptidases. Thus, the partial inhibition induced by EDTA can be explained by part of the $\mathrm{Ca}^{2+}$ ions essential for enzyme activity and the formation of milk-clot during the non-enzymatic phase of coagulation having been complexed with the chelating agent, and hence clotting was retarded (Hashem, 2000; Salehi et al., 2017).

Incubation of the purified enzyme with $0.02 \mathrm{mM}$ pepstatin $\mathrm{A}$, as a specific reversible inhibitor of aspartic peptidases, induced a strong inhibition of $94.5 \%$ compared to the control and reached $98.6 \%$ at $0.1 \mathrm{mM}$.

The MCE of M. circinelloides was more sensitive to pepstatin A inhibition than to aspartic peptidases from T. indicae-seudaticae N31 (Merheb-Dini et al., 2010) and M. mucedo DSM 809 (Yegin et al., 2012), where 75\% and 81\% of activity were suppressed at $0.02 \mathrm{mM}$ and $0.1 \mathrm{mM}$ of the same agent, respectively.

The results suggest the presence of aspartate residue at the active site of the enzyme and allow the inclusion of the peptidase produced by M. circinelloides in the aspartyl-peptidases family.

Salehi et al. (2017) reported that the very weak inhibition of aspartic peptidases by some inhibitors (E-64 and PMSF) was probably due to a small non-specific effect from the carrier solvents and/or the high concentrations of the inhibitors themselves.

Table 4 Effect of different inhibitors on MCA of the purified enzyme

\begin{tabular}{lll}
\hline Inhibitor & $\begin{array}{l}\text { Concentration } \\
(\mathrm{mM})^{\mathrm{a}}\end{array}$ & Residual MCA (\%) \\
\hline Control & 0 & 100 \\
PMSF & 1.0 & $89.87 \pm 0.80$ \\
2-mercaptoethanol & 2.0 & $87.65 \pm 1.46$ \\
& 5.0 & $98.50 \pm 1.00$ \\
EDTA & 10.0 & $93.70 \pm 0.92$ \\
& 5.0 & $74.20 \pm 2.62$ \\
& 7.0 & $72.73 \pm 1.81$ \\
Pepstatin-A & 10.0 & $34.78 \pm 1.71$ \\
& 14.0 & $21.82 \pm 2.17$ \\
& 0.02 & $5.44 \pm 0.03$ \\
& 0.06 & $2.88 \pm 0.07$ \\
\hline
\end{tabular}

The inhibitors were prepared in ethanol. ${ }^{a}$ is the final concentration of the inhibitor in the reaction mixture. MCA: milk-clotting activity.

The results were shown as mean value \pm standard deviation of three replicates. 


\section{Effect of metal ions}

Metallic ions such as $\mathrm{Fe}^{2+}, \mathrm{NH}_{4}{ }^{1+}, \mathrm{Zn}^{2+}$ and $\mathrm{Ba}^{2+}$ enhanced significantly the MCA of the purified enzyme by $11,13.3,24.5$ and $34.8 \%$, respectively at a concentration of $5 \mathrm{mM}$ (Fig 8). The MCA was strongly increased when using a concentration of $10 \mathrm{mM}$ of $\mathrm{Mg}^{2+}, \mathrm{Fe}^{2+}, \mathrm{Mn}^{2+}, \mathrm{Zn}^{2+}$ and $\mathrm{Ba}^{2+}$ where for the two last salts the percentage of activation reached 85 and $120 \%$ respectively.

The positive effects of $\mathrm{Fe}^{2+}, \mathrm{Mg}^{2+}, \mathrm{Mn}^{2+}$ and $\mathrm{Zn}^{2+}$ on the MCA of microbial coagulants have been reported by several studies (El-Bendary et al., 2007; Ahmed and Helmy, 2012; Ding et al., 2012; Sun et al., 2014; Li et al., 2019). Only Mabrouk et al. (1976) have reported the activating effect of $\mathrm{BaCl}_{2}$ for the coagulant of Penicillium expansum, whereas for others, it has an inhibitory effect (Sun et al., 2014)

The $\mathrm{K}^{1+}$ has no effect on the enzyme activity at $5 \mathrm{mM}$. After incubation with sodium, potassium and ammonium chloride at $10 \mathrm{mM}$, the purified enzyme exhibited residual MCA raging from $70-90 \%$. However, the other ions induced a significant inhibition specifically by $25.16,57.66$ and $85.5 \%$ with $\mathrm{Cu}^{2+}, \mathrm{Al}^{3+}$ and $\mathrm{Hg}^{2+}$, respectively, using a concentration of $5 \mathrm{mM}$. Similar findings have been obtained by He et al. (2011) and Ding et al. (2012). Increasing the concentration of $\mathrm{Al}^{3+}$ and $\mathrm{Hg}^{2+}$ inhibited strongly the enzyme activity to the extent of 93.1 and $94.4 \%$ respectively.

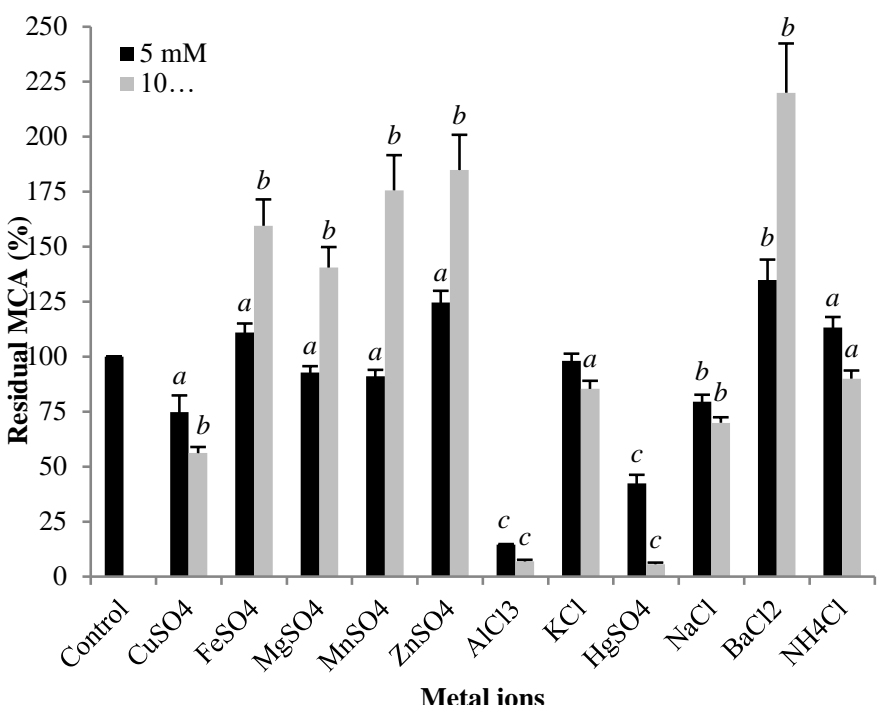

Figure 8 Influence of metallic salts on MCA of the purified enzyme. Error bars represent the standard deviation of three replicates. $(a: P<0.05 ; b: P<0.01 ; c: P$ $<0.001)$.

\section{$K_{m}$ and $V_{\max }$ determination}

The values of $K_{m}$ and $V_{\max }$ of the purified enzyme were calculated from the Lineweaver-Burk plot (Fig 9) as $125 \mathrm{mg} / \mathrm{mL}$ and $250 \mathrm{U} / \mathrm{mL}$, respectively using 1$3.5 \%$ of casein as the substrate at $\mathrm{pH}$ 5.2. Saturation of the enzyme activity was attained at a casein concentration of $3.5 \%(\mathrm{w} / \mathrm{v})$. The $K_{m}$ value was superior to $K_{m}$ values of coagulant enzymes that have been previously characterized (Kumar $\boldsymbol{e t}$ al., 2005; El-Tanboly et al., 2013; Salehi et al., 2017; Li et al., 2019).

According to Luo et al. (2018), a lower $K_{m}$ indicates a high enzyme affinity to the substrate when the substrate concentration is low, whereas a higher $K_{m}$ indicates a high enzyme affinity to the substrate only when the substrate concentration is higher. Thus, this difference can be attributed to the conditions followed during the proteolytic activity assay and the selected substrate concentration range.

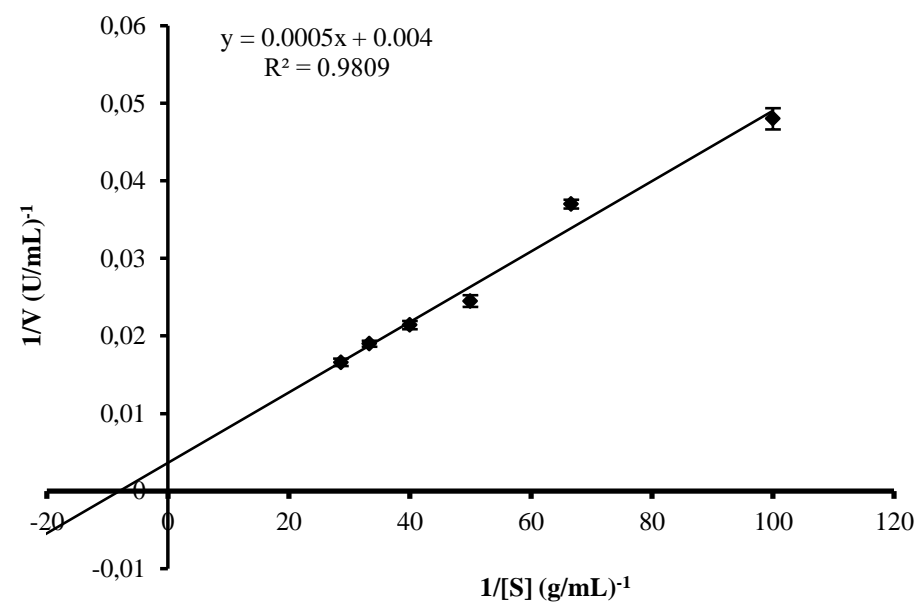

Figure $9 K_{m}$ and $V_{\max }$ determination using Lineweaver-Burk plot. Error bars represent the standard deviation of three replicates.

\section{Semi-hard cheese-making}

The dialyzed extract characterized by a high $\mathrm{MCA}=7333.33 \mathrm{SU} / \mathrm{mL}$ and MCA/PA ratio of 215.05, was selected for cheese making trials in comparison to the crude extract and commercial rennin CHY-MAX ${ }^{\circledR}$.

The cheese produced was Edam (ready for consumption), where the ripening procedure to develop flavor and body characteristics is normally lasts from 3 weeks at $10-18{ }^{\circ} \mathrm{C}$, depending on the extent of maturity required (FAO and OMS, 2018). According to the results (Tab 5), a small difference was observed between the chemical compositions of the two cheeses produced by CHY-MAX ${ }^{\mathbb{B}}$ chymosin and the dialyzed extract of $M$. circinelloides, which were compatible with the standards. Only the fat levels of cheeses made with the fungal extracts were higher than norms. The chemical properties of cheese produced by the crude extract were of low quality, because of its contamination by other constituents, such as nonspecific peptidases and possible lipases.

Cheese yield is important in cheese manufacture because of its direct impact on the process cost. The lowest yield $(72.7 \mathrm{~g} / \mathrm{L})$ was obtained for the crude extract, which was enhanced to reach $79 \mathrm{~g} / \mathrm{L}$ using the pre-purified extract from $M$. circinelloides, but it was still inferior to that of the commercial rennet. This difference can be explained by an excessive activity on proteins and fat content of milk (loss of proteins and fat in whey). The improvement of the cheese yield with the dialyzed extract indicated that the application of the two steps, $\left(\mathrm{NH}_{4}\right)_{2} \mathrm{SO}_{4}$ fractionation and dialysis, was able to reduce the degree of contamination by interfering enzymes, and thus we can predict that the purified extract, characterized by a low proteolytic activity, can achieve results very close to commercial chymosin.

Table 5 Characteristics of Edam cheeses produced by the fungal extracts of $M$. circinelloides or by CHY-MAX ${ }^{\circledR}$ rennin

\begin{tabular}{|c|c|c|c|c|}
\hline \multirow[b]{2}{*}{ Characteristics } & \multicolumn{3}{|c|}{ Cheese made with } & \multirow[b]{2}{*}{$\begin{array}{l}\text { Typical } \\
\text { values }\end{array}$} \\
\hline & $\begin{array}{l}\text { CHY- } \\
\mathrm{MAX}^{\circledR} \\
\text { rennin }\end{array}$ & $\begin{array}{l}\text { Crude extract } \\
\text { of } \\
M . \\
\text { circinelloides }\end{array}$ & $\begin{array}{c}\text { Dialyzed } \\
\text { extract of } M . \\
\text { circinelloides }\end{array}$ & \\
\hline $\mathrm{pH}$ & 5.50 & 4.90 & 5.49 & $5.1-5.5^{\mathrm{a}}$ \\
\hline Moisture (\%) & 43.90 & 37.30 & 40.90 & $38-53^{b}$ \\
\hline Dry matter $(\%)$ & 56.10 & 62.70 & 59.10 & $47-62^{b}$ \\
\hline Fat $(\%)$ & 23.00 & 25.00 & 25.00 & $20 \pm 1^{\mathrm{a}}$ \\
\hline FDM $(\%)$ & 41.00 & 39.87 & 42.30 & $40-50^{\mathrm{b}}$ \\
\hline Yield (g/L) & 84.12 & 72.70 & 79.00 & 1 \\
\hline
\end{tabular}

FDM: fat in dry matter. ${ }^{\text {a. }}$ (standards of the production unit) ${ }^{\text {b. }}$ (FAO and WHO, 2018).

The purified aspartic peptidase from $M$. circinelloides was used successfully in cheddar cheese making from fresh cows' milk with only a 5\% difference in the cheese yield compared to commercial rennet (Yegin et al., 2011). In this study, a difference of $6.086 \%$ was noted between the cheese yields attained by the dialyzed extract and CHY-MAX ${ }^{\circledR}$ rennin.

The detection and enumeration of Staphylococcus aureus (Baird Parker Agar at 37 ${ }^{\circ} \mathrm{C}$ for $48 \mathrm{~h}$, ISO 6888-1:1999 A1:2003) and Salmonella spp. pathogens (SeleniteF Broth for selective enrichment and Hektoen Enteric Agar for isolation at $37^{\circ} \mathrm{C}$ for $72 \mathrm{~h}$ ) in the cheeses produced revealed the total absence of contaminations, which indicated that the hygienic conditions were maintained during the cheese manufacture and the absence of germs in the fungal extracts.

For the physical properties, we have noted two remarkable defects: (1) unsuitable flavor (musty and pungent) only for cheese produced by the crude extract and (2) an uneven surface (internal appearance) for Edam given by the fungal extracts compared to a smooth texture for cheese made by $\mathrm{CHY}-\mathrm{MAX}^{\circledR}$ rennin. No 
difference was apparent for the color (buttery yellow) and the external appearance of all cheeses, but the consistency of cheese developed by the commercial rennin was softer and more flexible when compared to that resulting from the pre-purified extract.

\section{CONCLUSION}

The aspartic peptidase produced by $M$. cicrcinelloides (von Tieghem) using SSF system and purified by gel filtration on Sephadex G-100 was characterized by a high specific MCA of $20202 \mathrm{SU} / \mathrm{mg}$, low proteolytic activity, thermostability up to $45^{\circ} \mathrm{C}$; $\mathrm{pH}$ stability in the acidic range with an optimum at $\mathrm{pH} 5.0$, lower $\mathrm{CaCl}_{2}$ sensitivity with maximum activity at a concentration of $25 \mathrm{mM}$, and were very close to the properties of calf rennet. Incorporation of $\mathrm{NaCl}$ in the milk even at $1 \%$ $(w / v)$ affected strongly the curdling activity of the enzyme. The MCA of the purified enzyme was significantly enhanced by metallic ions $\mathrm{Mg}^{2+}, \mathrm{Fe}^{2+}, \mathrm{Mn}^{2+}$ $\mathrm{Zn}^{2+}$ and $\mathrm{Ba}^{2+}$, but appreciably inhibited by $\mathrm{Al}^{3+}$ and $\mathrm{Hg}^{2+}$

The results obtained in cheese making trials are promising, but in order to achieve the aim of the study, the purification process needs to be improved to get a purified enzyme that can be considered as a possible substitute for rennin based upon the most important properties for cheese making. Moreover, it is essential to complete our work by studying the proteolytic properties of the enzyme and their influence on the quality of the fungal coagulant, which allows the choice of cheese varieties to be produced. $M$. circinelloides is not known to produce mycotoxins, but it will be necessary to make toxicity studies for the microorganism and for the produced enzyme solution to be safely applicable in cheese production. Finally, cheesemanufacturing tests using the purified enzyme separately or in combination with commercial rennet to reduce the amount of this coagulant and production costs could be very interesting.

Acknowledgement: The authors are grateful to the Company of milk and cheese production of Boudouaou (Boumerdes, Algeria) for support and facilities during the cheese making trials.

This work was supported by the National Committee for Evaluation and Programming of the University Research (CNEPRU No.D01N01UN350120120009), Ministry of Higher Education and Scientific Research of Algeria.

\section{REFERENCES}

AHLAWAT, S., KUMAWAT, M., BABELE, P. K. 2018. Microbial enzymes in food technology. In M. KUDDUS (ed.), Enzymes in food technology: Improvements and innovations (pp. 1-19). Springer Nature Singapore Pte Ltd https://doi.org/10.1007/978-981-13-1933-4_1

AHMED, S. A., HELMY, W. A. 2012. Comparative evaluation of Bacillus licheniformis 5A5 and Aloe variegate milk-clotting enzymes. Brazilian Journal of Chemical Engineering, 29(1), 69-76. https://doi.org/10.1590/s010466322012000100008

ALJAMMAS, H. A., AL-FATHI, H., ALKHALAF, W. 2018. Study the influence of culture conditions on rennin production by Rhizomucor miehei using solid-state fermentations. Journal of Genetic Engineering and Biotechnology, 16(1), 213-216. https://doi.org/10.1016/j.jgeb.2017.10.004

ANSON, M. L. 1938. The estimation of pepsin, trypsin, papain and cathepsin with haemoglobin. Journal of General Physiology, 22(1), 79-89. https://doi.org/10.1085/jgp.22.1.79

ARDÖ, Y., POLYCHRONIADOU, A. 1999. Laboratory manual for chemical analysis of cheese. Luxemburg: European Communities, Office for Official Publications of the European Communities, 123 p. ISBN 92-828-6599-1.

ARIMA, K., YU, J., IWASAKI, S. 1970. Milk clotting enzyme from Mucor pusillus var. Lindt. In G. PERLMANN \& L. LORAND (Eds.), Methods in enzymology (pp. 446-459). New York, USA: Academy Press. https://doi.org/10.1016/0076-6879(70)19033-1

AWAD, S. 2007. Effect of sodium chloride and $\mathrm{pH}$ on the rennet coagulation and gel firmness. LWT-Food Science and Technology, 40(2), 220-224. https://doi.org/10.1016/j.lwt.2005.10.007

BENLOUNISSI, A., MECHAKRA-MAZA, A., BLUM, L. J., MARQUETTE, C. A. 2014. Identification and characterization of milk-clotting proteases produced by two species of mold. African Journal of Biotechnology, 13(11), 1275-1280. https://doi.org/10.5897/ajb2013.13162

BRADFORD, M. M. 1976. A rapid and sensitive method for the quantitation of microgram quantities of protein utilizing the principle of protein-dye binding Analytical Biochemistry, 72(1-2), 248-254. https://doi.org/10.1016/00032697(76)90527-3

BURGESS, R. R. 2009. Protein precipitation techniques. In R. R. BURGESS \& M. P. DEUSTCHER (Eds.), Methods in enzymology: Guide to protein purification (pp. 332-342). USA: Academic Press-Elsevier. https://doi.org/10.1016/s00766879(09)63020-2

CELEBI, M., TOPUZOGULLARI, M., KUZU, H. 2016. Thermal destabilization of Rhizomucor miehei rennet with aldehyde dextran sulfate: Purification, bioconjugation and milk-clotting activities. Applied Biochemistry and Biotechnology, 180(2), 261-273. https://doi.org/10.1007/s12010-016-2097-5
DING, Z., WANG, W., WANG, B., OUYANG, A., XIAO, S., WANG, Y., LIU, S., DING, M., ZHANG, L., SHI, G. 2012. Production and characterization of milkclotting enzyme from Bacillus amyloliquefaciens JNU002 by submerged fermentation. European Food Research and Technology, 234(3), 415-421. https://doi.org/10.1007/s00217-011-1650-2

EL-BENDARY, M. A., MOHARAM, M. E., ALI, H. T. 2007. Purification and characterization of milk-clotting enzyme production by Bacillus sphaericus Journal of Applied Sciences Research, 3(8), 695-699. http://www.aensiweb.com/old/jasr/jasr/2007/695-699.pdf

EL-TANBOLY, E. S., EL-HOFI, M., BAHR YOUSSEF, Y., EL-DESOKI, W., ISMAIL, A. 2013. Utilization of salt whey from egyptian ras (Cephalotyre) cheese in microbial milk clotting enzymes production. Journal Acta Scientiarum Polonorum Technologia Alimentaria, 12(1), 9-19. https://www.food.actapol.net/pub/1_1_2013.pdf

FAZOUANE-NAIMI, F., MECHAKRA, A., ABDELLAOUI, R., NOUANI, A., MAGAGI DAGA, S., MAROU ALZOUMA, A., GAIS, S., PENNINCKX, M. J. 2010. Characterization and cheese-making properties of rennet-like enzyme produced by a local Algerian isolate of Aspergillus niger. Food Biotechnololy, 24(3), 258-269. https://doi.org/10.1080/08905436.2010.507149

Food and Agriculture Organization of the United Nations and World Health Organization (FAO/WHO), CXS 265-1966: Standard for Edam, Codex Alimentarius-International Food Standards. Adopted in 1966, Revised in 2007, Amended in 2008, 2010, 2013, 2018. Available from: http://www.fao.org/faowho-codexalimentarius/codex-texts/list-standards/en/

GUERRAND, D. 2017. Lipases industrial applications: focus on food and agroindustries. Oilseeds \& fats Crops and Lipids, 24(4), D403. https://doi.org/10.1051/ocl/2017031

GUINEE, T. P., O'BRIEN, B. 2010. The quality of milk for cheese manufacture In B. A. LAW \& Y. A. TAMIME (Eds.), Technology of cheesemaking (pp. 1-67) Oxford, UK: Wiley-Blackwell, A John Wiley \& Sons, Ltd. Publication. https://doi.org/10.1002/9781444323740.ch1

GULERIA, S., WALIA, A., CHAUHAN, A., SHIRKOT, C. K. 2016. Optimization of milk-clotting enzyme production by Bacillus amyloliquefaciens SP1 isolated from apple rhizosphere. Bioresources \& Bioprocessing. 3(1), 30 https://doi.org/10.1186/s40643-016-0108-6

HARBOE, M., BROE, M. L., QVIST, K. B. 2010. The production, action and application of rennet and coagulants. In B. A. LAW \& Y. A. TAMIME (Eds.), Technology of cheesemaking (pp. 98-129). Oxford, UK: Wiley-Blackwell, A John Wiley \& Sons, Ltd., Publication. https://doi.org/10.1002/9781444323740.ch3

HASHEM, A. 2000. Purification and properties of a milk-clotting enzyme produced by Penicillium oxalicum. Bioresource Technology, 75(3), 219-222 https://doi.org/10.1016/s0960-8524(00)00055-9

HE, X., REN, F., GUO, H., ZHANG, W., SONG, X., GAN, B. 2011. Purification and properties of a milk-clotting enzyme produced by Bacillus amyloliquefaciens D4. Korean Journal of Chemical Engineering, 28(1), 203-208. https://doi.org/10.1007/s11814-010-0347-8

HIROSE, H. 2012. Production and isolation of enzymes. In. K. DRAUZ, H GRÖGER \& O. MAY (Eds.), Enzyme catalysis in organic synthesis: A comprehensive handbook (pp. 191-215). Germany: Wiley-VCH Verlag GmbH \& Co. KGaA. https://doi.org/10.1002/9783527639861.ch6

ILLANES, A. 2008. Enzyme Production. In A. ILLANES (Ed.), Enzyme biocatalysis: Principles and applications (pp. 57-106). Netherlands: Springer Science + Business Media B.V. https://doi.org/10.1007/978-1-4020-8361-7_2 KHALIL MOGHADDAM, SH., KHALEGHIAN, M., NADERI, F., AZIN, M., MONAJJEMI, M. 2008. Purification and characterization of milk-clotting enzyme produced by Rhizomucor miehei. Journal of Physical \& Theoretical Chemistry $5(3)$,

$149-154$

http://jptc.srbiau.ac.ir/article_6758_2706b5af6dc7936f9716a42251accb07.pd KUMAR, A., GROVER, S., SHARMA, J., BATISH, V. K. 2010. Chymosin and other milk coagulants: sources and biotechnological interventions. Critical $\begin{array}{llll}\text { Reviews in } & \text { Biotechnology, } & \text { 30(4), } & \text { 243-258 }\end{array}$ https://doi.org/10.3109/07388551.2010.483459

KUMAR, S., SHARMA, N. S., SAHARAN, M. R., SINGH, R. 2005. Extracellular acid protease from Rhizopus oryzae: purification and characterization. Process Biochemistry, 40(5), 1701-1705. https://doi.org/10.1016/j.procbio.2004.06.047

LAEMMLI, U. K. 1970. Cleavage of structure proteins during assembly of the head of bacteriophage T4. Nature, 227(5259), 680-685. https://doi.org/10.1038/227680a0

LI, L., ZHENG, Z., ZHAO, X., WU, F., ZHANG, J., YANG, Z. 2019. Production, purification and characterization of a milk clotting enzyme from Bacillus methanolicus LB-1. Food Science and Biotechnology, https://doi.org/10.1007/s10068-018-0539-2

LUO, J., XIAO, C., ZHANG, H., REN, F., LEI, X., YANG, Z., YU, Z. 2018. Characterization and milk coagulating properties of Cynanchum otophyllum Schneid. proteases. Journal of Dairy Science, 101(4), 1-9. https://doi.org/10.3168/jds.2017-13888

MABROUK, S. S., AMR, A. S., ABDEL-FATTAH, A. F. 1976. A Rennin-like enzyme from Penicillium expansum. Agricultural \& Biological Chemistry. 40(2), 419-420. https://doi.org/10.1271/bbb1961.40.419 
MACIEL, G. M., HAMMERSHØJ, M., FREDERIKSEN, P. D., SØRENSEN, J., BAKMAN, M., POULSEN, N. A., LARSEN, L. B. 2015. Dairy processing and cold storage affect the milk coagulation properties in relation to cheese production. Dairy Science \& Technology, 95(1), 101-114. https://doi.org/10.1007/s13594. 014-0202-5

MAMO, J., ASSEFA, F. 2018. The role of microbial aspartic protease enzyme in food and beverage industries. Journal of Food Quality, 2018, 115. https://doi.org/10.1155/2018/7957269

MERHEB-DINI, C., GOMES, E., BOSCOLO, M., DA SILVA, R. 2010 Production and characterization of a milk-clotting protease in the crude enzymatic extract from the newly isolated Thermucor indicae-seudaticae N31 (Milk-clotting protease from the newly isolated Thermomиcor indicae-seudaticae N31). Food Chemistry, 120(1), 87-93. https://doi.org/10.1016/j.foodchem.2009.09.075

MONEY, N. P. 2016. Fungi and biotechnology. In S. C. WATKINSON, L. BODDY \& N. P. MONEY (Eds.), The fungi (pp. 401-424). UK: Academic Press, Elsevier. https://doi.org/10.1016/b978-0-12-382034-1.00012-8

NASR, A. I. A. M., MOHAMED AHMED, I. A., \& HAMID, O. I. A. 2016. Characterization of partially purified milk-clotting enzyme from sunflower (Helianthus annuus) seeds. Food Science \& Nutrition, 4(5), 733-741. https://doi.org/10.1002/fsn3.338

NOUANI, A., BELHAMICHE, N., SLAMANI, R., BELBRAOUET, S., FAZOUANE, F., BELLAL, M. M. 2009. Extracellular protease from Mucor pusillus: purification and characterization. International Journal of Dairy Technology, 62(1), 112-117. https://doi.org/10.1111/j.1471-0307.2008.00454.x PREETHA, S., BOOPATHY, R. 1997. Purification and characterization of a milk clotting protease from Rhizomисor miehei. World Journal of Microbiology and Biotechnology, 13(5), 573-578. https://doi.org/10.1023/A:1018525711573

SALEHI, M., AGHAMAALI, M. R., SAJEDI, R. H., ASGHARI, S. M., JORJANI, E. 2017. Purification and characterization of a milk-clotting aspartic protease from Withania coagulans fruit. International Journal of Biological Macromolecules, 98, 847-854. https://doi.org/10.1016/j.ijbiomac.2017.02.034

SHAH, M. A., MIR, S. A., PARAY, M. A. 2014. Plant proteases as milk-clotting enzymes in cheesemaking: a review. Dairy Science \& Technology, 94(1), 5-16. https://doi.org/10.1007/s13594-013-0144-3

SILVA, B. L., GERALDES, F. M., MURARI, C. S., GOMES, E., DA-SILVA, R. 2013. Production and characterization of a milk-clotting protease produced in submerged fermentation by the thermophilic fungus Thermoтисоr indicaeseudaticae N31. Applied Biochemistry and Biotechnology, 172(4), 1999-2011. https://doi.org/10.1007/s12010-013-0655-7

SUN, Q., WANG, X.-P., YAN, Q.-J., CHEN, W., JIANG, Z.-Q. 2014. Purification and characterization of a chymosin from Rhizopus microsporus var. rhizopodiformis. Applied Biochemistry and Biotechnology, 174(1), 174-185. https://doi.org/0.1007/s12010-014-1044-6

THERON, L. W., DIVOL, B. 2014. Microbial aspartic proteases: current and potential applications in industry. Applied Microbiology and Biotechnology, 98(21), 8853-8868. https://doi.org/10.1007/s00253-014-6035-6

TUNGA, R., BANERJEE, R., BHATTACHARYA, B. C. 1998. Optimizing some factors affecting protease production under solid-state fermentation. Bioprocess Engineering, 19, 187-190. http:/doi.org/10.1007/s004490050504

VISHWANATHA, K. S., RAO APPU, A. G., SIGH, S. A. 2010. Production and characterization of a milk-clotting enzyme from Aspergillus oryzae MTCC 5341 Applied Microbiology and Biotechnology, 85(6), 1849-1859. https://doi.org/10.1007/s00253-009-2197-z

WALSH, G. 2014. Proteins: biochemistry and biotechnology. Oxford, UK: Wiley Blackwell, A John Wiley and Sons Ltd. 431 p. ISBN 978-0-470-66986-0 (cloth) ISBN 978-0-470-66985-3 (pbk.). https://doi.org/10.1002/9781119117599

WU, F.-C., CHANG, C.-W., SHIH, I.-L. 2013. Optimization of the production and characterization of milk clotting enzymes by Bacillus subtilis natto. SpringerPlus, 2(1), 33. https://doi.org/10.1186/2193-1801-2-33

YEGIN, S., DEKKER, P. 2013. Progress in the field of aspartic proteinases in cheese manufacturing: structures, functions, catalytic mechanism, inhibition, and engineering. Dairy Science \& Technology, 93(6), 565-594. https://doi.org/10.1007/s13594-013-0137-2

YEGIN, S., FERNANDEZ-LAHORE, M., GAMA SALGADO, A. J., GUVENC, U., GOKSUNGUR, Y., TARI, C. 2011. Aspartic proteinases from Mucor spp. in cheese manufacturing. Applied Microbiology and Biotechnology, 89(4), 949-960. https://doi.org/10.1007/s00253-010-3020-6

YEGIN, S., GOKSUNGUR, Y., FERNANDEZ-LAHORE, M. 2012. Purification, structural characterization and technological properties of an aspartyl proteinase from submerged cultures of Mucor mucedo DSM 809. Food Chemistry, 133(4), 1312-1319. https://doi.org/10.1016/j.foodchem.2012.01.075

ZIKIOU, A., ZIDOUNE, M. N. 2018. Enzymatic extract from flowers of Algerian spontaneous Cynara cardunculus: Milk-clotting properties and use in the manufacture of a Camembert-type cheese. International Journal of Dairy Technology, 72(1), 89-99. http://doi.org/10.1111/1471-0307.12563 